\section{TINJAUAN YURIDIS TERHADAP PELANGGARAN KEPABEANAN DI KAWASAN PERBATASAN ${ }^{1}$ \\ Oleh : Raelma Meisyelha}

ABSTRAK
Tujuan dilakukannya penelitian ini yaitu untuk mengetahui bagaimana aturan hukum mengenai kepabeanan di kawasan perbatasan dan bagaimana penegakan hukum terhadap pelanggaran kepabeanan di kawasan perbatasan di mana dengan metode penelitian hukum normatif disimpulkan: 1. Aturan hukum kepabeanan di kawasan perbatasan yang berlaku saat ini adalah Undang-Undang Nomor 17 Tahun 2006 tentang perubahan atas Undang-Undang Nomor 10 Tahun 1995 Tentang Kepabeanan. Dilakukannya perubahan dikarenakan sebagian pasal dalam aturan tersebut tidak sejalan lagi dengan perkembangan zaman dan tuntutan dari masyarakat. Adapun aturan yang mendukung pelaksanaan UU kepabeanan diantaranya yaitu Peraturan Menteri Keuangan Nomor 80/PMK.04/2019, Peraturan Menteri Keuangan Nomor 1043/KM.4/2018, Peraturan Menteri Keuangan Nomor 100/PMK.04/2018, Peraturan Dirjen Bea Cukai Nomor 6/BC/2016, dan Peraturan Menteri Keuangan Nomor 148/PMK.04/2011. Selain UU Kepabeanan, Undang-undang Nomor 39 Tahun 2007 tentang perubahan atas Undang-Undang Nomor 11 Tahun 1995 Tentang Cukai dan Peraturan Pemerintah Nomor 34 Tahun 2019 tentang Perdagangan Perbatasan. Dalam pengaturan hukum kepabeanan terdapat aturan hukum yang terkait diantaranya Hukum Keuangan negara dan Hukum Perdagangan Internasional. 2. Dalam penegakan hukum terhadap pelanggaran kepabeanan dikawasan perbatasan, Direktorat Jenderal Bea dan Cukai sebagai penegak hukum di bidang kepabeanan memiliki peran yang sangat penting dalam memberantas pelanggaran-pelanggaran yang terjadi. Penegakan hukum yang dilakukan DirJen Bea dan Cukai berupa pengawasan, penyidikan dan pemberian sanksi terhadap pelaku yang melakukan pelanggaran. Dalam melaksanakan penegakan hukum DirJen Bea

\footnotetext{
1 Artikel Skripsi. Dosen Pembimbing: Prof. Dr. Telly sumbu, SH, MH; Nelly Pinangkaan, $\mathrm{SH}, \mathrm{MH}$

2 Mahasiswa pada Fakultas Hukum Unsrat, NIM. 16071101269
}

dan Cukai memiliki kewenangan untuk mengawasi lalu lintas barang di kawasan Indonesia terutama di wilayah yang berbatasan dengan negara lain, baik darat maupun laut. Pejabat Bea dan Cukai dalam melakukan pengawasan kemudian menemukan suatu pelanggaran maka dilakukan penindakan untuk menyelesaikan pelanggaran tersebut, apabila pelanggaran itu merupakan tindak pidana maka akan dilakukan penyidikan dan pemberian sanksi pidana, sedangkan untuk pelanggaran administrasi maka dikenakan sanksi administrasi. Pemberian sanksi kepabeanan baik berupa sanksi administrasi maupun sanksi pidana telah diatur jelas dalam Undang-Undang Nomor 17 Tahun 2006 tentang perubahan atas Undang-Undang Nomor 10 Tahun 1995 Tentang Kepabeanan.

Kata kunci: kepabeanan; kawasan perbatasan;

\section{PENDAHULUAN}

\section{A. Latar Belakang}

Undang-Undang Nomor 17 Tahun 2006 Tentang Kepabeanan mendefinisikan pengertian impor, ekspor dan antar pulau (barang tertentu) $)^{3}$. Dalam pasal 1 angka 13 dinyatakan bahwa yang dimaksud dengan impor adalah kegiatan memasukkan barang ke dalam daerah pabean. Lebih lanjut ditetapkan dalam pasal 2 bahwa barang yang dimasukkan ke dalam daerah pabean diperlakukan sebagai barang impor dan terutang bea masuk.

\section{B. Rumusan Masalah}

1. Bagaimana aturan hukum mengenai kepabeanan di kawasan perbatasan?

2. Bagaimana penegakan hukum terhadap pelanggaran kepabeanan di kawasan perbatasan?

\section{Metode Penelitian}

Penulisan yang digunakan dalam penulisan skripsi ini adalah penulisan deskriptif sebagai salah satu bentuk penelitian hukum Normatif.

\footnotetext{
3 Abidin Zainal, Modul Tugas dan Fungsi Direktorat Jenderal Bea dan Cukai, Pusdiklat Bea dan Cukai, Jakarta, 2011, hlm. 4
} 


\section{PEMBAHASAN}

\section{A. Aturan Hukum Kepabeanan Di Kawasan Perbatasan}

Hukum pabean sebagai hukum nasional tunduk pada filosofi dan prinsip dasar hukum yang dianut pada hukum negara. Republik Indonesia dan pemerintah negara yang berdasarkan hukum (rechstaat) secara prinsip menghendaki terwujudnya hukum nasional yang mantap dan mengabdi kepada kepentingan nasional yang bersumber pada Pancasila dan Undang-Undang Dasar (UUD) $1945^{4}$.

1. Undang-Undang Nomor 17 Tahun 2006 tentang perubahan atas Undang-Undang Nomor 10 Tahun 1995 tentang Kepabeanan.

Peraturan perundang-undang kepabeanan yang saat ini berlaku diantaranya yaitu UndangUndang Nomor 17 Tahun 2006 tentang perubahan atas Undang-Undang Nomor 10 Tahun 1995 tentang Kepabeanan. Perubahan dilakukan karena adanya tuntutan dari masyarakat karena perkembangan zaman dimana sebagian dari aturan yang ada di dalam Undang-Undang Nomor 10 Tahun 1995 tidak sejalan lagi dengan keadaan masyarakat saat ini dan penyesuaian dengan ketentuan-ketentuan Internasional khususnya di bidang kepabeanan yaitu standar dari organisasi WCO karena Indonesia telah tergabung menjadi anggota organisasi WCO.

Agreement on Implementation of Article VII of General Agreement on Trade and Tariff (GATT) 1994, Article 22 menyebutkan bahwa perundang-undangan nasional harus memuat ketentuan penetapan nilai pabean sesuai World Trade Organization (WTO) Valuation Agreement. Dalam Article 4 Konvensi tersebut diatur bahwa metode komputasi dapat digunakan mendahului metode deduksi atas permintaan importir. Indonesia telah menggunakan kesempatan untuk menunda pelaksanaan Article 4 konvensi tersebut selama 5 (lima) tahun yang berakhir pada tahun 2000, sehingga ketentuan penetapan nilai pabean sesuai Article 4 konvensi tersebut harus dimasukkan dalam perubahan Undang-Undang Kepabeanan ini ${ }^{5}$.

\footnotetext{
${ }^{4}$ Sutarto Eddhi, op. cit, hlm. 33

${ }^{5}$ Penjelasan atas undang-undang nomor 17 tahun 2006 tentang perubahan atas undang-undang nomor 10 tahun 1995 tentang kepabeanan, I. Umum
}

Dilakukannya juga perubahan terhadap UU kepabeanan menunjukkan bahwa adanya upaya dari Direktorat Jenderal Bea dan Cukai untuk mengadakan perbaikan dalam meningkatkan kinerjanya menuju kesetaraan dengan kinerja kepabeanan. Dalam perubahan undang-undang ini terdapat 52 pasal yang diubah dan 36 pasal yang di tambah serta terdapat 14 pasal yang di hapus dimana sebagian besar adalah ketentuan untuk menghindari kekosongan hukum. Adapun halhal baru dalam Undang-Undang Nomor 17 Tahun 2006 tentang Kepabeanan yaitu ketentuan tentang Bea Masuk Anti Dumping, Bea Masuk Imbalan, Pengendalian Impor atau Ekspor barang hasil pelanggaran Hak Atas Kekayaan Intelektual, Pembukuan, Sanksi Administrasi, Penyidikan, dan Lembaga Banding $^{6}$. Dalam pasal 2 Undang-Undang Nomor 17 Tahun 2006 yang berbunyi:

(1) Barang yang dimasukkan ke dalam daerah pabean diperlakukan sebagai barang impor dan terutang bea masuk;

(2) Barang yang telah dimuat di sarana pengangkutan untuk dikeluarkan dari daerah pabean dianggap telah diekspor dan diperlakukan sebagai barang ekspor;

(3) Barang sebagaimana dimaksud pada ayat (2) bukan merupakan barang ekspor dalam hal dapat dibuktikan bahwa barang tersebut ditujukan untuk dibongkar di suatu tempat dalam daerah pabean.

Pasal ini merupakan dasar yuridis bagi pejabat Bea dan Cukai dalam melakukan pengawasan. Barang yang telah dimuat di sarana pengangkutan untuk dikeluarkan dari daerah pabean dianggap telah diekspor dan diperlakukan sebagai barang ekspor. Secara nyata ekspor terjadi pada saat barang melintasi daerah pabean, namun mengingat dari segi pelayanan dan pengamanan tidak mungkin menempatkan Pejabat Bea dan Cukai di sepanjang garis perbatasan untuk memberikan pelayanan dan melakukan pengawasan ekspor barang, maka secara yuridis ekspor dianggap telah terjadi pada saat barang tersebut sudah dimuat di sarana pengangkutan yang akan berangkat ke luar daerah pabean ${ }^{7}$. Lebih lanjut mengingat barang yang dimasukkan ke dalam

\footnotetext{
${ }^{6}$ Sutedi Adrian, Aspek Hukum Kepabeanan, Sinar Grafika, Jakarta 2012, hlm.263

${ }^{7}$ Ibid, hlm. 268
} 
daerah pabean diperlakukan sebagai barang impor dan terutang bea masuk sebagaimana yang di atur dalam pasal 2, walaupun barang yang di selundupkan tertangkap petugas Bea dan Cukai (Customs) atau petugas lainnya, tetapi barang selundupan tersebut sudah masuk ke dalam daerah pabean, maka hak pungut negara berupa bea masuk dan pajak tetap melekat pada barang itu, sehingga pemilik barang itu terutang bea masuk dan pajak Pemerintah Negara Republik Indonesia ${ }^{8}$.

2. Undang-Undang Nomor 39 Tahun 2007 Tentang Perubahan Atas Undang-Undang Nomor 11 Tahun 1995 Tentang Cukai

Peraturan perundang-undangan tentang kepabenan tidak terlepas yang dinamakan CUKAI. Undang-Undang tentang cukai memiliki hubungan yang erat dalam pengaturan tentang kepabeanan terlebih di kawasan perbatasan sehingga dikenal Direktorat Jenderal Bea dan Cukai. Dalam pelaksanaan Undang-Undang Nomor 11 Tahun 1995 tentang Cukai, disadari masih terdapat hal-hal yang belum tertampung untuk memberdayakan peranan cukai sebagai salah satu sumber penerimaan negara sehingga Undang-Undang Nomor 11 Tahun 1995 tentang Cukai dilakukan perubahan sejalan dengan perkembangan sosial ekonomi dan kebijakan pemerintah ${ }^{9}$. Dalam pasal 4 Undang-Undang Cukai dijelaskan mengenai barang-barang yang dikenakan cukai, adapun bunyi dari pasal 4 yaitu:

(1) Cukai dikenakan terhadap barang kena cukai yang terdiri dari:

a. Etil alkohol atau etanol, dengan tidak mengindahkan bahan yang digunakan dan proses pembuatannya;

b. Minuman yang mengandung etil alkohol dalam kadar berapa pun, dengan tidak mengindahkan bahkan yang digunakan dan proses pembuatannya, termasuk konsentrat yang mengandung etil alkohol;

c. Hasil tembakau, yang meliputi segaret, cerutu, rokok daun, tembakau iris, dan hasil pengolahan tembakau lainnya,

\footnotetext{
${ }^{8}$ Sukinto, Yudi Wibowo, Tindak Pidana Penyelundupan Di Indonesia, Kebijakan Formulasi Sanksi Pidana, Sinar Grafika, Jakarta, 2015, hlm. 9

${ }^{9}$ Penjelasan Atas Undang-Undang Nomor 39 Tahun 2007 Tentang Perubahan Atas Undang-Undang Nomor 11 Tahun 1995 Tentang Cukai, I. Umum
}

dengan tidak mengindahkan digunakan atau tidak bahan pengganti atau bahan pembantu dalam pembuatannya.

(2) Penambahan atau pengurangan jenis barang kena cukai diatur lebih lanjut dengan peraturan pemerintah.

Penetapan jenis barang kena cukai sebagaimana yang telah disebutkan dalam pasal 4 maka saat ini secara umum kita mengenal tiga jenis barang kena cukai, yaitu etil alkohol, minuman yang mengandung etil alkohol, dan hasil tembakau. Disebutkan dalam pasal 2 Undang-Undang Nomor 39 Tahun 2007, terhadap barang kena cukai yaitu barangbarang tertentu yang mempunyai sifat dan karakteristik yaitu yang:

a. Konsumsinya perlu dikendalikan;

b. Peredarannya perlu diawasi;

c. Pemakaiannya dapat menimbulkan dampak negatif bagi masyarakat atau lingkungan hidup; atau

d. Pemakaiaanya perlu pembebanan pungutan negara demi keadilan dan keseimbangan, dikenai cukai berdasarkan undang-undang ini.

Cukai sebagai pungutan negara yang dikenakan terhadap barang-barang tertentu yang mempunyai sifat dan karakteristik sesuai dengan undang-undang ini merupakan penerimaan negara guna mewujudkan kesejahteraan, keadilan dan keseimbangan, terlebih untuk memperjelas sistem administrasi pungutan cukai demi mengantisipasi terjadinya pelanggaran-pelanggaran yang dilakukan oleh oknum-oknum tertentu.

Pengecualian terhadap barang kena cukai yang tidak dilakukan pemungutan cukai disebutkan dalam pasal 8 Undang-Undang Nomor 39 Tahun 2007, sedangkan untuk pembebasan cukai diatur dalam pasal 9. Sedangkan terhadap pelanggaran cukai dan sanksinya diatur dalam pasal 16 ayat (4) dan ayat (5), pasal 16B, pasal 25 , pasal 26, pasal 27, pasal 29, pasal 31, pasal 32.

3. Aturan Hukum Yang Terkait Dengan Aturan Hukum Kepabeanan

Ketentuan Hukum di bidang kepabeanan meliputi himpunan norma yang dituangkan dalam undang-undang yang mengatur pengawasan lalu lintas barang ekspor dan impor dan pungutan bea. Oleh karena itu, dalam pelaksanaannya sangat terkait dengan 
ketentuan hukum di luar ketentuan hukum di bidang kepabeanan antara lain hukum keuangan negara, hukum perdagangan internasional.

\section{B. Penegakan Hukum Terhadap Pelanggaran Kepabeanan Di Kawasan Perbatasan}

Direktorat Jenderal Bea dan Cukai adalah salah satu organisasi dari Kementerian Keuangan yang mempunyai tugas menyelenggarakan perumusan dan pelaksanaan kebijakan di bidang pengawasan, penegakan hukum, pelayanan, dan optimalisasi penerimaan negara di bidang kepabeanan dan cukai sesuai dengan ketentuan peraturan perundang-undangan yang berlaku (Pasal 20 Peraturan Presiden Nomor 28 Tahun 2015 tentang Kementerian Keuangan) ${ }^{10}$. Penegakan hukum yang dilakukan oleh bea cukai erat kaitannya dengan fungsi bea cukai selaku pemangku amanat undang-undang kepabeanan oleh karena itu, bea dan cukai mempunyai landasan hukum yang jelas agar dapat melaksanakan tugasnya yaitu Undang-Undang Kepabeanan Nomor 17 Tahun 2006.

Dalam melaksanakan penegakan hukum Direktorat Jenderal Bea dan Cukai memiliki kewenangan untuk mengawasi lalu lintas barang di kawasan Indonesia, terutama di wilayah yang berbatasan dengan negara lain, baik di darat, laut, dan udara, maupun tempat lain yang ditetapkan untuk lalu lintas barang. Dalam modul pencegahan pelanggaran kepabeanan yang di buat oleh word customs organization (WCO) disebutkan bahwa pengawasan pabean merupakan salah satu metode untuk mencegah dan mendeteksi pelanggaran kepabeanan ${ }^{11}$. Pengawasan dapat dilakukan dari jauh maupun dari dekat. Pengawasan dari jauh disebut pemantauan atau monitoring ini dapat dilakukan menggunakan sarana telepon, fax, atau radio. Wujud pengawasan cara ini adalah permintaan laporan kepada bawahan dan jawaban dari bawahan atas permintaan tersebut. jika pengawasan dari jauh tidak efektif dapat dilakukan pemeriksaan yang berarti pemeriksa

10 Alfiani Indah, Skirpsi Pencegahan Tindak Pidana Kepabeanan di Pelabuhan Soekarno Hatta Makassar, Fakultas Hukum Universitas Hasanuddin, Makassar, 2016, hlm. 31

${ }^{11}$ Sutedi Adrian, op.cit, hlm. 62 berhadapan langsung dengan objek yang diperlukan ${ }^{12}$.

Pelanggaran-pelanggaran Kepabeanan yang disebutkan dalam WCO sebagian besar yang sering terjadi adalah pelanggaran pengimporan atau pengeksporan terkait perizinan. Tipe pelanggaran ini memiliki informasi yang lebih banyak dan lebih mudah diperoleh dari dokumen-dokumen yang diajukan pada Bea dan Cukai. Sedangkan tipe pelanggaran pemberitahuan yang tidak benar, penyalahgunaan fasilitas kepabeanan, pelanggaran impor sementara dan sebagainya lebih mudah dideteksi melalui dokumen impor/ekspor yang berada di kantor pelayanan informasi tentang adanya pelanggaranpelanggaran tersebut bisa diperoleh jika mengolah informasi-informasi dalam pemberitahuan impor barang (PIB), pemberitahuan Ekspor barang (PEB), manifest, Bill of lading $(\mathrm{B} / \mathrm{L})$, invoice, Packing list, data perusahaan, data kapal, data kontainer, dan lain-lain. Informasi ini sebagian besar berada di kantor pelayanan dan dapat digunakan setiap saat $^{13}$.

Petugas Bea Cukai yang meneliti dokumen pada hakikatnya sedang melakukan pengawasan sebab petugas meneliti apakah importir memberitahukan tarif pos dengan benar sesuai peraturan tentang klasifikasi atau memberitahukan harga barang dengan benar sesuai peraturan tentang penetapan harga. Demikian juga petugas yang melakukan pemeriksaan barang impor pada hakikatnya melakukan pengawasan karena ia meneliti apakah importir memberitahukan jumlah dan jenis barang sesuai dengan peraturan yang berlaku ${ }^{14}$. Terhadap Pelanggaran penyelundupan yang terjadi di luar tempat kedudukan bea dan cukai informasinya harus dicari langsung di lapangan. Pada umumnya yang dianggap informasi bagi orang awam adalah pemberitahuan dari seseorang atau badan secara tertulis atau lisan bahwa akan terjadi penyelundupan yang dilakukan oleh seseorang. Informasi yang sudah matang ini di

\footnotetext{
${ }^{12}$ Reza Abdi Esa S Baideng, Fungsi Dirjen Bea Cukai dalam Pencegahan Penyelundupan Senjata di Indonesia, (https://ejournal.unsrat.ac.id/index.php/lexetsocietatis/ar ticle/view/5398), Diunduh pada tanggal 25 oktober 2019, pukul 13.46

${ }^{13}$ Sutedi Adrian, Op.cit, hlm.73

${ }^{14}$ Ibid
} 
Bea Cukai lazim disebut hasil intelijen atau intelijen positif ${ }^{15}$. Dalam melaksanakan penegakan hukum pejabat bea dan cukai harus bersikap tegas dalam melaksanakan pengawasan demi memberantas pelanggaranpelanggaran kepabeanan.

Pejabat Bea dan cukai dalam mengamankan negara melekat banyak wewenang untuk menunjang pengawasan dalam menegakkan undang-undang dan peraturan yang berlaku. Wewenang itu meliputi wewenang memakai senjata api dalam tugas, wewenang penindakan patroli, mendapat bantuan instansi lain, penegahan, melakukan penyegelan, periksa fisik terhadap surat, periksa fisik terhadap bangunan, periksa fisik terhadap alat angkut, periksa fisik terhadap badan, melakukan audit $^{16}$.

\section{a. Memakai senjata api}

Pasal 74 Undang-Undang Nomor 10 Tahun 1995 tentang Kepabeanan memberikan wewenang untuk memakai senjata api dalam melaksanakan penegakan hukum, pada ayat 1 menyatakan "dalam melaksanakan tugas berdasarkan undangundang ini dan peraturan-perundangundangan lain yang pelaksanaannya dibebankan kepada Direktorat Jenderal, pejabat Bea dan Cukai untuk mengamankan hak-hak negara berwenang mengambil tindakan yang diperlukan terhadap barang" lebih lanjut pada pasal 2 "dalam melaksanakan kewenangan sebagaimana dimaksud pada ayat (1), pejabat Bea dan Cukai dapat dilengkapi dengan senjata api jenis dan syarat-syarat penggunaannya diatur dengan peraturan pemerintah". Dalam memakai senjata api diberi batasan dalam penggunaannya karena mengingat besarnya bahaya bagi keselamatan dan keamanan.

b. Wewenang penindakan patroli

Pejabat Bea dan Cukai dalam melaksanakan pengawasan terhadap sarana pengangkutan di laut atau di sungai menggunakan kapal patroli atau sarana lainnya. Kapal patroli atau sarana lain yang digunakan oleh pejabat Bea dan Cukai sebagaimana dimaksud dapat dilengkapi dengan senjata api yang jumlah dan

\footnotetext{
${ }^{15}$ Sutedi Adrian, op.cit, hlm. 74

${ }^{16}$ Bambang Semedi, op. cit, hlm. 9
}

jenisnya ditetapkan dengan peraturan pemerintah ${ }^{17}$. Maksud dan tujuan dilakukannya patroli yaitu untuk mengawasi agar sarana pengangkutan melewati jalur yang ditetapkan dan mencegah terjadinya pelanggaranpelanggaran di bidang kepabeanan dan juga untuk mencegah terjadinya kerugian uang negara.

c. Mendapat bantuan instansi lain

Dalam melaksanakan tugas berdasarkan undang-undang ini pejabat bea dan cukai dapat meminta bantuan Kepolisian Republik Indonesia, Tentara Nasional Indonesia, dan/atau instansi lainnya. Atas permintaan sebagaimana dimaksud Kepolisian Republik Indonesia, Tentara Nasional Indonesia, dan/atau instansi lainnya berkewajiban untuk memenuhinya ${ }^{18}$.

d. Penegahan

Penegahan diatur dalam pasal 77 UndangUndang Nomor 10 Tahun 1995 yang menyatakan "untuk dipenuhinya kewajiban pabean berdasarkan undang-undang ini, pejabat Bea dan Cukai berwenang menengah barang dan/atau sarana pengangkut. Tindakan ini dilakukan untuk menunda pengeluaran, pemuatan, dan pengangkutan barang impor, ekspor. Syarat penegahan adalah barang diduga kuat merupakan barang hasil atau digunakan sebagai tindakan pelanggaran, dan hanya dapat dilakukan oleh petugas unit pengawasan ${ }^{19}$.

e. Penyegelan

Penyegelan dilakukan untuk mengamankan barang yang belum menyelesaikan kewajiban pabeannya. Terhadap wewenang penyegelan diatur dalam pasal 78 UndangUndang Nomor 17 Tahun 2006.

f. Pemeriksaan fisik

Dalam melakukan pemeriksaan fisik, baik pemeriksaan fisik terhadap surat, bangunan, alat angkut, badan diatur dalam pasal 82A, pasal 85, dan pasal 85A UndangUndang Nomor 17 Tahun 2006.

\footnotetext{
17 Undang-undang nomor 17 tahun 2006 tentang perubahan atas undang-undang nomo 10 tahun 1995 tentang kepabeanan pasal 75

${ }^{18} \mathrm{Ibid}$, pasal 76

${ }^{19}$ Bambang semedi, Op.cit, hlm.4
} 
g. Melakukan Audit

Pejabat Bea dan Cukai berwenang melakukan audit kepabeanan terhadap orang yang melakukan pembukuan sebagaimana yang dimaksud dalam pasal 49 undang-undang kepabanan. Dalam melaksanakan audit kepabeanan, pejabat Bea dan Cukai berwenang meminta laporan keuangan, buku, catatan dan dokumen yang menjadi bukti dasar pembuktian ${ }^{20}$. Dalam melakukan audit diatur dalam pasal 86 Undang-Undang Nomor 17 Tahun 2006.

Wewenang kepabeanan tersebut dalam melakukan penindakan terhadap barang dan/atau sarana pengangkutan serta bangunan atau tempat lain adalah suatu wewenang yang bersifat administratif dalam rangka menjamin hak-hak negara dan dipatuhinya ketentuan larangan dan pembatasan. Dalam pelaksanaannya dituntut kesadaran yang tinggi berdasarkan persyaratan yang ditetapkan dan bersifat objektif. Pejabat Bea dan Cukai yang melaksanakan penindakan harus telah mempunyai petunjuk yang cukup atas tindakan yang akan diambilnya dan tetap mengutamakan tingkat pelayanan yang tinggi serta memberikan kepastian bagi pemilik barang dan orang yang dikenakan penindakan. Setiap penindakan harus dapat dipertanggungjawabkan secara hukum berdasarkan alasan dan bukti yang cukup untuk mendapatkan penyelesaian akhir berupa penyidikan terhadap pelanggaran tindak pidana atau pengenaan sanksi administratif berupa denda ${ }^{21}$.

Penindakan yang dilakukan oleh pejabat bea cukai saat ini dapat dikatakan sudah berjalan dengan baik sebagai contoh kasus penindakan yang berhasil dilakukan dimana bea cukai melakukan penindakan masif Rokok, Elektrik, dan Miras llegal. Dalam penindakan yang dilakukan secara sinergis oleh penegak hukum dalam hal ini bea cukai, petugas berhasil mengamankan sebuah truk bermuatan 2.410.800 batang rokok tanpa pita cukai. Rokok tersebut berasal dari jawa tengah dan akan dikirim ke wilayah Sumatera. Potensi kerugian

\footnotetext{
${ }^{20}$ Bambang semedi, op.cit, hlm. 9

21 Suradi Saulus, Terjadinya Pelanggaran Hukum Kepabeanan menurut Undang-Undang Nomor 10 tahun 1995, Fakultas Hukum Universitas Yos Soedarso, Surabaya 2019, hlm. 8
}

negara ditaksir mencapai Rp 891,9 juta dan saat ini sedang dilakukan proses penyelidikan lebih lanjut. Tidak hanya di wilayah serang, Banten, bea cukai sebelumnya juga berhasil melakukan penindakan di wilayah Tembilahan, Riau. Dari penindakan ini diperoleh 5.619 .520 batang rokok tanpa pita cukai dengan potensi kerugian negara ditaksir mencapai Rp 2,4 miliar. Selain penindakan yang telah disebutkan masih terdapat banyak penindakan yang berhasil dilakukan oleh bea cukai. Seluruh penindakan itu menambah daftar panjang penindakan bea cukai. Berdasarkan data pada 2018, jumlah penindakan rokok ilegal yang dilakukan bea cukai mencapai 5.436 kasus, sementara di 2019, hingga saat ini bea cukai telah melakukan penindakan terhadap 4.724 kasus $^{22}$.

Diundangkannya UU No 10 Tahun 1995 yang telah dirubah menjadi UU No 17 Tahun 2006 tentang Kepabeanan dan UU No 11 Tahun 1995 yang telah dirubah dengan UU No 39 Tahun 2007 tentang Cukai, Pejabat Pegawai Negeri Sipil tertentu di lingkungan Direktorat Jenderal Bea dan Cukai diberi wewenang sebagai Penyidik untuk melakukan penyidikan tindak pidana di bidang Kepabeanan dan Cukai.

Dalam melakukan penyidikan tehadap tindak pidana di bidang kepabeanan dan menghadapi perkembangan dalam tindak kuantitas maupun kualitasnya, diperlukan profesionalisme dalam penyidikan. Namun tidak menutup kemungkinan dalam "situasi tertentu" penyidikan terhadap tindak pidana di bidang kepabeanan dan cukai dapat dilakukan oleh Penyidik Kepolisian Negara Republik Indonesia. Yang dimaksud dengan "dalam situasi tertentu" adalah keadaan yang tidak memungkinkan dilakukannya penyidikan oleh Penyidik Pegawai Negeri Sipil Direktorat Jenderal Bea dan Cukai atau tertangkap tangan oleh pejabat polisi negara Republik Indonesia untuk barang-barang yang dikeluarkan di luar Kawasan Pabean. Dalam menjalankan tugasnya penyidik bea cukai diberi wewenang: ${ }^{23}$

\footnotetext{
${ }^{22}$ Tempo.co, Bea Cukai Lakukan Penindakan Masif Rokok, Elektrik, Miras Ilegal, (https://nasional.tempo.co/amp/1264477/bea-cukailakukan-penindakan-masif-rokok-elektrik-miras-ilegal), Diunduh pad tanggal 26 oktober 2019, pukul 22.00

${ }^{23}$ Milyana Risydan Al Anshori, Penguatan Bea Cukai secara Kelembagaan dalam Menghadapi Kejahatan Transnasional, Jurnal IImiah "DUNIA HUKUM" VOL. 1 NO. 1, 2016, hlm. 53
} 
(1) Menerima laporan atau keterangan dari seseorang tentang adanya tindak pidana di bidang Kepabeanan;

(2) Memanggil orang untuk didengar dan diperiksa sebagai tersangka atau saksi;

(3) Meneliti, mencari, dan mengumpulkan keterangan dengan tindak pidana di bidang Kepabeanan;

(4) Melakukan penangkapan dan penahanan terhadap orang yang disangka melakukan tindak pidana di bidang Kepabeanan;

(5) Meminta keterangan dan bukti dari orang yang disangka melakukan tindak pidana di bidang Kepabeanan;

(6) Memotret dan/atau merekam melalui media audiovisual terhadap orang, barang, sarana pengangkut, atau apa saja yang dapat dijadikan bukti adanya tindak pidana di bidang Kepabeanan;

(7) Memeriksa catatan dan pembukuan yang diwajibkan menurut undang-undang ini dan pembukuan lainnya yang terkait;

(8) Menggeleda tempat atau sarana pengangkutan dan memeriksa barang yang terdapat di dalamnya apabila dicurigai adanya tindak pidana di bidang kepabeanan;

(9) Menggeledah rumah tinggal, pakaian, atau badan, dan lain sebagainya.

Pejabat Bea dan Cukai dalam melakukan pengawasan dan menemukan pelanggaranpelanggaran di bidang kepabeanan maka bea cukai sebagai penegak hukum akan menindaki pelanggaran tersebut berupa pemberian sanksi. Dalam penegakan hukum di bidang kepabeanan pemberian sanksi merupakan cara yang efektif untuk dilakukan. Sebagaimana telah dijelaskan sebelumnya bahwa ketentuan pelanggaran kepabeanan dibagi kedalam dua kelompok yaitu pelanggaran administratif dan pelanggaran tindak pidana, sehingga dalam memberikan sanksi disesuaikan dengan masing-masing jenis pelanggaran, sanksi pelanggaran tersebut berupa sanksi administrasi dan sanksi pidana.

a. Pemberian sanksi Administrasi

Pemberian sanksi administrasi terbagi dalam dua jenis yaitu sanksi berupa denda dan sanksi berupa selain denda. Sanksi administrasi selain denda ini dapat berwujud pemblokiran, pembekuan, pencabutan izin atau sanksi lain berupa $i^{24}$. Namun dalam praktik kepabeanan

\footnotetext{
${ }^{24}$ Giman, Sanksi Administrasi di Bidang Kepabeanan,
} (https://pakgiman.com/sanksi-administrasi-di-bidang- di beberapa negara, penanganan pelanggaran kepabeanan lebih dititik beratkan pada penyelesaian secara fiskal, yaitu berupa pembayaran sejumlah uang kepada negara dalam bentuk denda ${ }^{25}$.

Undang-Undang kepabeanan pada dasarnya menganut asas menghitung dan menyetor sendiri bea masuk atau bea keluar yang terhutang oleh importir atau eksportir (self assesment). Sistem self assesment memberikan kepercayaan yang besar kepada para pengguna jasa kepabeanan. Namun, kepercayaan tersebut harus diimbangi dengan tanggung jawab, kejujuran, dan kepatuhan dalam pemenuhan ketentuan undang-undang yang berlaku ${ }^{26}$, sehingga apabila pengguna jasa kepabeanan dalam rangka pemenuhan kewajiban kepabeanan melakukan tindakan pelanggaran, maka pengaturan selanjutnya berupa pengenaan sanksi administrasi.

Penerapan sanksi administrasi pada hakikatnya merupakan kewajiban yang dapat memberatkan mereka yang terkena. Maka penerapannya harus memenuhi kriteria yang transparan agar dapat dicegah terjadinya ketidakpastian dalam menetapkan sanksi administrasi ${ }^{27}$. Tujuan pemberian sanksi administrasi sendiri yaitu untuk memulihkan hak-hak negara dan juga menjamin dipatuhinya aturan-aturan yang telah diatur dalam ketentuan perundang-undangan. Hal terpenting bahwa sanksi administrasi berupa denda hanya dapat dikenakan terhadap pelanggaran yang diatur secara jelas dalam undang-undang, dalam hal ini Undang-Undang Nomor 17 Tahun 2006 tentang perubahan atas Undang-Undang Nomor 10 Tahun 1995 Tentang Kepabeanan. Hal tersebut dinyatakan dalam pasal 2 ayat 1 Peraturan Pemerintah Nomor 28 Tahun 2008 tentang Pengenaan Sanksi Administrasi Berupa Denda Di Bidang Kepabenan yang telah dirubah dengan Peraturan Pemerintah Nomor 39 Tahun 2019 yang berbunyi "sanksi administrasi berupa denda dikenakan hanya terhadap pelanggaran yang diatur dalam undang-undang".

Pasal-pasal Pengenaan sanksi administrasi berupa denda dalam undang-undang kepabeanan dinyatakan dalam nilai rupiah tertentu, nilai rupiah minimum sampai dengan maksimum, persentase tertentu dari bea masuk yang

kepabeanan/), Diunduh pada tanggal 26 oktober 2019, pukul 22:30

${ }^{25}$ Sutarto Eddhi, Op.cit, hlm. 105

${ }^{26}$ Giman, Loc.cit

${ }^{27}$ Sutarto Eddhi, op.cit, hlm. 106 
seharusnya dibayar, persentase tertentu minimum sampai dengan maksimum dari kekurangan pembayaran bea masuk atau bea keluar, dan persentase tertentu minimum sampai dengan maksimum dari bea masuk yang seharusnya dibayar.

Sanksi administrasi yang dinyatakan dalam nilai rupiah tertentu diatur dalam pasal $10 \mathrm{~A}$ ayat (8), pasal $11 \mathrm{~A}$ ayat (6), pasal 45 ayat (3), pasal 52 ayat (1) dan ayat (2), pasal 81 ayat (3), pasal 82 ayat (3) huruf b, pasal 86 ayat (2), pasal 89 ayat (4), pasal 90 ayat (4), dan pasal 91 ayat (4) Undang-Undang Nomor 17 Tahun 2006 tentang perubahan atas Undang-Undang Nomor 10 Tahun 1995 Tentang Kepabeanan. Dalam pasal-pasal ini terhadap sanksi administrasi yang dikenakan terhadap pelanggaranpelanggaran ketentuannya dinyatakan dalam nilai tertentu, misalnya pasal $10 \mathrm{~A}$ ayat (8) menyatakan "orang yang mengeluarkan barang impor dari kawasan pabean atau tempat lain sebagaimana dimaksud, setelah memenuhi semua ketentuan tetapi belum mendapat persetujuan pengeluaran dari pejabat Bea dan Cukai, dikenai sanksi administrasi berupa denda sebesar Rp 25.000.000,00 (dua puluh lima juta rupiah).

Sanksi administrasi berupa nilai rupiah minimum sampai dengan maksimum diatur dalam pasal 7A ayat (7) dan ayat (8), pasal 8A ayat (2) dan ayat (3), pasal 8C ayat (3) dan ayat (4), pasal 9A ayat (3), dan pasal 10A ayat (3) dan ayat (4) undang-undang kepabeanan. Besarnya denda yang dinyatakan dalam nilai rupiah minimum sampai dengan maksimum ditetapkan secara berjenjang dengan ketentuan bilamana dalam (6) bulan terakhir terjadi:

(1) 1 (satu) kali pelanggaran, dikenai denda sebesar 1 (satu) kali denda minimum;

(2) 2 (dua) kali pelanggaran, dikenai denda sebesar 2 (dua) kali denda minimum;

(3) 3 (tiga) sampai dengan 4 (empat) kali pelanggaran, dikenai denda sebesar 5 (lima) kali denda minimum;

(4) 5 (lima) sampai 6 (enam) kali pelanggaran, dikenai denda sebesar 7 (tujuh) kali denda minimum;

(5) Lebih dari 6 (enam) kali pelanggaran, dikenai denda sebesar 1 (satu) kali denda maksimum.

Sebagai contoh, pada tangal 15 juli, pengangkut barang impor di perbatasan melakukan pelanggaran, yaitu jumlah barang impor yang dibongkar kurang dari yang diberitahukan dalam pemberitahuan pabean, sehingga berdasarkan undang-undang dikenai sanksi administrasi berupa denda paling sedikit Rp25.000.000,00 (dua puluh lima juta rupiah) dan paling banyak Rp250.000.000,00 (dua ratus lima puluh juta rupiah). Untuk mengenakan sanksi administrasi berupa denda maka harus dilihat jumlah pelanggaran yang dilakukan oleh pengangkut tersebut dalam kurun waktu 6 (enam) bulan terakhir dihitung sejak tanggal terjadinya pelanggaran terakhir. Apabila dalam kurun waktu 6 (enam) bulan tersebut, pengangkut melakukan 3 (tiga) kali pelanggaran, maka dikenai denda 5 (lima) kali dari denda minimum, yaitu sebesar $\mathrm{Rp}$ 125.000.000,00 (seratus dua puluh lima juta rupiah) ${ }^{28}$.

Pemberian denda yang besarnya dinyatakan dalam persentase tertentu dari bea masuk yang seharusnya di bayar terdapat dalam pasal 10B ayat (6), pasal 10D ayat (5) dan ayat (6), pasal 43 ayat (3), dan pasal 45 ayat (4) UndangUndang Kepabeanan. Dalam pengaturan pasal ini dinyatakan bahwa denda administrasi $10 \%$ dari bea masuk yang seharusnya dibayar.

Sanksi administrasi yang dendanya dinyatakan dalam persentase tertentu minimum sampai dengan maksimum dari kekurangan pembayaran bea masuk atau keluar diatur dalam pasal 16 ayat (4), pasal 17 ayat (4), pasal 82 ayat (5) dan ayat (6), dan pasal 86A. Besarnya denda yang dinyatakan dalam persentase tertentu minimum sampai dengan maksimum dari kekurangan pembayaran bea masuk atau bea keluar ditetapkan secara berjenjang berdasarkan perbandingan antara kekurangan pembayaran, seperti yang disebutkan dalam pasal 16 ayat (4) yang berbunyi "importir yang salah memberitahukan nilai pabean untuk penghitungan bea masuk sehingga mengakibatkan kekurangan pembayaran bea masuk dikenai sanksi administrasi berupa denda paling sedikit $100 \%$ (seratus persen) dari bea masuk yang kurang dibayar dan paling banyak $1000 \%$ (seribu persen) dari bea masuk yang kurang dibayar.

Sanksi administrasi yang dinyatakan dalam persentase tertentu minimum sampai dengan maksimum dari Bea masuk yang seharusnya hanya terdapat dalam pasal 25 ayat (4), dan pasal 26 ayat (4) Undang-Undang Kepabeanan. Dalam pasal 25 ayat (4) menyebutkan bahwa "orang yang tidak memenuhi ketentuan tentang pembebasan bea masuk yang ditetapkan menurut undang-undang ini wajib membayar

\footnotetext{
${ }^{28}$ Giman, Loc. cit
} 
bea masuk yang terutang dan dikenai sanksi administrasi berupa denda sebesar paling sedikit $100 \%$ (seratus persen) dari bea masuk yang seharusnya dibayar dan paling banyak 500\% (lima ratus persen) dari bea masuk yang seharusnya dibayar. Sedangkan pasal 26 ayat (4) menyebutkan "orang yang tidak memenuhi ketentuan pembebasan atau keringanan bea masuk yang ditetapkan menurut undang-undang ini wajib membayar bea masuk yang terutang dan dikenai sanksi administrasi berupa denda sebesar paling sedikit 100\% (seratus persen) dari bea masuk yang seharusnya dibayar dan paling banya $500 \%$ (lima ratus persen) dari bea masuk yang seharusnya dibayar. Besarnya denda yang dinyatakan dalam persentase minimum sampai dengan maksimum dari bea masuk yang seharusnya dibayar ditetapkan secara berjenjang berdasarkan perbandingan antara bea masuk atas fasilitas yang disalahgunakan dengan total bea masuk yang dapat mendapat fasilitas ${ }^{29}$.

b. Pemberian sanksi Pidana

Pelanggaran kepabeanan yang dikenal dengan Custom Fraud, seperti yang telah dijelaskan sebelumnya bahwa pelanggaran kepabeanan terbagi dua yaitu yang bersifat administrasi dan pidana. Pada umumnya yang berkaitan dengan pidana kepabeanan didominasi dengan tindak pidana penyelundupan, yang lainnya terkait dengan pemalsuan sampai pidana yang dilakukan oleh badan hukum ${ }^{30}$.

Pemberian sanksi pidana terhadap pelanggaran tindak pidana penyelundupan dalam hal ini di bidang impor dan ekspor, secara lengkap diatur dalam pasal 102 dan 102A Undang-Undang Nomor 17 Tahun 2006 tentang perubahan atas Undang-Undang Nomor 10 Tahun 1995 Tentang Kepabeanan. Dalam pemberian sanksi terhadap pelanggaran tindak pidana penyelundupan di bidang impor dapat dipidana paling singkat 1 (satu) tahun dan pidana penjara paling lama 10 (sepuluh) tahun, selain pidana penjara dapat juga dikenakan pidana denda sesuai yang disebutkan dalam pasal tersebut. Lebih lanjut bahwa pelanggaran sebagaimana yang disebutkan dalam pasal 102 dan pasal 102A yang mengakibatkan terganggunya sendi-sendi perekonomian negara dipidana dengan pidana penjara paling singkat 5 (lima) tahun dan pidana penjara paling lama 20 (dua puluh) tahun dan pidana denda paling sedikit Rp5.000.000.000,00 (lima miliar rupiah)

\footnotetext{
${ }^{29}$ Giman, Loc. cit

${ }^{30}$ Sutarto Eddhi, Op.cit, hlm. 107
}

dan paling banyak Rp100.000.000.000,00 (seratus miliar rupiah) $)^{31}$. Adapun contoh kasus pemberian sanksi pidana terhadap penyelundupan di kawasan perbatasan yang berhasil di gagalkan oleh bea cukai yaitu bea cukai berhasil menggagalkan penyelundupan 2.861 karung pakaian bekas dari Timor Leste diperairan Tanjung Tuakau dan Laut Alor, Nusa Tenggara Timur. Bea cukai dalam mengambil penindakan pertama yaitu melakukan penangkapan kapal "Harapan Bersama" berbendera Indonesia di perairan poros Alfandega dan kapal KM "Karya Bersama". Kemudian kapal dan barang muatan tersebut dibawa ke pelabuhan Atapupu, Atambua, NTT untuk pemeriksaan lebih lanjut. Tersangka yang melakukan penyelundupan tersebut dijerat dengan pasal 102 dengan ancaman pidana penjara maksimal 10 tahun dan denda maksimal senilai Rp5.000.000.000,00 (lima miliar rupiah )$^{32}$.

\section{PENUTUP}

\section{A. Kesimpulan}

1. Aturan hukum kepabeanan di kawasan perbatasan yang berlaku saat ini adalah Undang-Undang Nomor 17 Tahun 2006 tentang perubahan atas Undang-Undang Nomor 10 Tahun 1995 Tentang Kepabeanan. Dilakukannya perubahan dikarenakan sebagian pasal dalam aturan tersebut tidak sejalan lagi dengan perkembangan zaman dan tuntutan dari masyarakat. Adapun aturan yang mendukung pelaksanaan UU kepabeanan diantaranya yaitu Peraturan Menteri Keuangan Nomor 80/PMK.04/2019, Peraturan Menteri Keuangan Nomor 1043/KM.4/2018, Peraturan Menteri Keuangan Nomor 100/PMK.04/2018, Peraturan Dirjen Bea Cukai Nomor 6/BC/2016, dan Peraturan Menteri Keuangan Nomor 148/PMK.04/2011. Selain UU Kepabeanan, Undang-undang Nomor 39 Tahun 2007 tentang

\footnotetext{
31 Undang-undang nomor 17 tahun 2006 tentang perubahan atas undang-undang nomor 10 tahun 1995 tentang kepabenan, pasal 102B

${ }^{32}$ Aditya Mardiastuti, Bea Cukai Gagalkan Penyelundupan 2.861 Karung Pakaian Bekas dari Timor Leste, (https://m.detik.com/news/berita/d-4668484/bea-cukaigagalkan-penyelundupan-2861-karung-pakaian-bekasdari-timor-leste), Diunduh pada tanggal 26 oktober 2019, pukul 23.00
} 
perubahan atas Undang-Undang Nomor 11 Tahun 1995 Tentang Cukai dan Peraturan Pemerintah Nomor 34 Tahun 2019 tentang Perdagangan Perbatasan. Dalam pengaturan hukum kepabeanan terdapat aturan hukum yang terkait diantaranya Hukum Keuangan negara dan Hukum Perdagangan Internasional.

2. Dalam penegakan hukum terhadap pelanggaran kepabeanan dikawasan perbatasan, Direktorat Jenderal Bea dan Cukai sebagai penegak hukum di bidang kepabeanan memiliki peran yang sangat penting dalam memberantas pelanggaran-pelanggaran yang terjadi. Penegakan hukum yang dilakukan DirJen Bea dan Cukai berupa pengawasan, penyidikan dan pemberian sanksi terhadap pelaku yang melakukan pelanggaran. Dalam melaksanakan penegakan hukum DirJen Bea dan Cukai memiliki kewenangan untuk mengawasi lalu lintas barang di kawasan Indonesia terutama di wilayah yang berbatasan dengan negara lain, baik darat maupun laut. Pejabat Bea dan Cukai dalam melakukan pengawasan kemudian menemukan suatu pelanggaran maka dilakukan penindakan untuk menyelesaikan pelanggaran tersebut, apabila pelanggaran itu merupakan tindak pidana maka akan dilakukan penyidikan dan pemberian sanksi pidana, sedangkan untuk pelanggaran administrasi maka dikenakan sanksi administrasi. Pemberian sanksi kepabeanan baik berupa sanksi administrasi maupun sanksi pidana telah diatur jelas dalam Undang-Undang Nomor 17 Tahun 2006 tentang perubahan atas Undang-Undang Nomor 10 Tahun 1995 Tentang Kepabeanan.

\section{B. Saran}

1. Dalam menghadapi perkembangan zaman dan perkembangan perdagangan dimasa sekarang ini perlu dilakukan perbaikan lagi terhadap aturan hukum mengenai kepabeanan untuk memberikan pemahaman yang lebih lagi kepada masyarakat terhadap aturan yang mengatur dalam melakukan kegiatan kepabeanan terlebih bagi masyarakat yang berada di kawasan perbatasan. Sejauh ini memang peraturan perundang-undang kepabeanan yaitu UU No 17 Tahun 2006 sudah dapat dikatakan baik, namun dalam hal pengaturan jenisjenis pelanggaran, baik pelanggaran administrasi maupun pelanggaran pidana alangkah lebih baiknya jika diuraikan dalam 1 pasal, dan untuk pemberian sanksinya di ikuti oleh pasal lainya. Selain itu aturan kepabeanan juga perlu dilakukan keselarasan dengan ketentuanketentuan Internasional tentang perdagangan dan kepabeanan.

2. Penegakan hukum yang dilakukan Dirjen Bea Cukai dalam memberantas pelanggaran kepabeanan dapat dikatakan sudah berjalan dengan baik, terbukti banyaknya kasus pelanggaran yang berhasil digagalkan dan ditindaki oleh pejabat penegak hukum. Namun diharapkan kepada Dirjen Bea dan Cukai untuk tidak lalai dan lebih memperketat lagi pengawasan dalam mencegah terjadinya pelanggaran kepabeanan mengingat besarnya kerugian negara yang diakibatkan oleh pelanggaranpelanggaran tersebut, dan diharapkan juga bagi Dirjen Bea Cukai sebagai penegak hukum untuk menjalankan ketentuan peraturan perundang-undang secara konsisten dan tidak menerima suap dari pihak yang secara nyata melakukan pelanggaran.

\section{DAFTAR PUSTAKA}

Abdul Sani dan kawan-kawan, Buku Pintar Kepabeanan, PT Gramedia Pustaka Utama, Jakarta, 2007.

Abidin Zainal, Modul Tugas dan Fungsi Direktorat Jenderal Bea dan Cukai, Pusdiklat Bea dan Cukai, Jakarta, 2011.

Alfiani Indah, Skirpsi Pencegahan Tindak Pidana Kepabeanan di Pelabuhan Soekarno Hatta Makassar, FH Universitas Hasanuddin, Makassar, 2016.

Burhanudin, S, Prosedur Hukum Pengurusan Bea dan Cukai, Pustaka Yustisia, Yogyakarta, 2013. 
Capt R Suyono,Shipping ; Pengangkutan Intermodal Ekspor Impor melalui Laut, Ed Revisi 2 PPM, Jakarta, 2003

Daeng Nazir, Post Audit dalam Sistem Kepabeanan di Indonesia, Makalah Seminar Nasional UU Kepabeanan dan UU Cukai, Surabaya,1996.

Felix Hadi Mulyanto dan Endar Sugiarto, Pabean, Imigrasi, dan karantina, PT.Gramedia Pustaka Utama, Jakarta, 1997.

Kementerian Perencanaan Pembangunan Nasional/BAPPENAS,RPJMN 2010-2014, Direktorat Kawasan Khusus dan Daerah Tertinggal, Jakarta, 2010.

Milyana Risydan Al Anshori, Penguatan Bea Cukai secara Kelembagaan dalam Menghadapi Kejahatan Transnasional, Jurnal Ilmiah "DUNIA HUKUM" VOL. 1 NO. 1, 2016.

Purwito M, Ali, Kepabeanan dan Cukai Lalu Lintas Barang, Konsep dan aplikasinya, Cetakan Keempat, Kajian Hukum Fiskal FHUI, 2010.

Samekto FX.Adji, Negara Dalam Dimensi Hukum Internasional, Bandung: Citra Aditya Bhakti, 2009.

Sugianto, Pengantar Kepabeanan dan Cukai, Grasindo, Jakarta, 2008.

Sukinto, Yudi Wibowo, Tindak Pidana Penyelundupan Di Indonesia, Kebijakan Formulasi Sanksi Pidana, Sinar Grafika, Jakarta, 2015

Sunarno, Sistem dan prosedur kepabeanan di Bidang Ekspor, pusdiklat Bea dan Cukai, Jakarta, 2007

Suradi Saulus, Terjadinya Pelanggaran Hukum Kepabeanan menurut Undang-Undang Nomor 10 tahun 1995, Fakultas Hukum Universitas Yos Soedarso, Surabaya, 2019.

Suryo Sakti Handiwijoyo, Batas Wilayah Negara Indonesia: Dimensi, Permasalahan, Dan Strategi Penanganan, Gava Media, Yogyakarta, 2009.

Sutarto Eddhi, Rekontruksi Sistem Hukum Pabean Indonesia, Erlangga, Jakarta, 2010.

Sutedi Adrian, Aspek Hukum Kepabeanan, Sinar Grafika, Jakarta, 2012. 